\title{
MODIFIKASI KAIN AKTIF ANTIBAKTERI BERBASIS KOMPLEK Mn(II) BASA SCHIFF KITOSAN-SALISILALDEHID
}

\section{(MODIFICATION OF ANTIBACTERIAL FABRIC FROM Mn(II) SCHIFF BASE CHITOSAN - SALICYLALDEHYDE COMPLEX)}

\author{
Ismiyarto, Sesika Novari, Ngadiwiyana, Purbowatiningrum Ria Sarjono, \\ dan Noor Basid Adiwibawa Prasetya \\ Fakultas Sains dan Matematika Universitas Diponegoro \\ J1. Prof. Sudharto SH., Tembalang, Semarang 50275 \\ email: ismiyarto@live.undip.ac.id
}

\begin{abstract}
Abstrak
Penelitianini bertujuan untuk memperoleh kompleks Mn(II)-basa Schiff kitosan-salisaldehida dan menguji aktivitasnya sebagai bahan aktif kain antibakteri. Metode penelitian dilakukan melalui tiga tahapan. Pada tahap pertama dilakukan sintesis basa Schiff kitosan-salisilaldehid dengan mereaksikan kitosan dengan variasi mol salisilaldehid menggunakan campuran pelarut asam asetat dan etanol, diaduk pada suhu $50^{\circ} \mathrm{C}$ selama 6 jam. Pada tahap kedua, basa Schiff kitosan-salisilaldehid dijadikan kompleks dengan $\mathrm{MnCl} 2.2 \mathrm{H} 2 \mathrm{O}$ menggunakan campuran pelarut asam asetat $2 \%$ dan etanol, diaduk pada suhu $60^{\circ} \mathrm{C}$ selama 12 jam. Pada tahap ketiga dilakukan pelapisan kompleks pada kain katun menggunakan metode spray dan selanjutnya dilakukan uji antibakteri terhadap E. coli (G-) dan $S$. aureus $\left(\mathrm{G}^{+}\right)$menggunakan metode difusi cakram. Hasil penelitian menunjukkan bahwa basa Schiff kitosan-salisilaldehid dengan rasio substitusi paling besar $(0,122)$ diperoleh ketika disintesis menggunakan salisilaldehid 0,00227 mol. Senyawa kompleks Mn(II)-basa Schiff kitosan-salisilaldehid yang terbentuk berupa serbuk berwarna hitam dengan rendemen 66\%. Kain katun yang telah dilapisi kompleks Mn(II)-basa Schiff kitosan-salisilaldehid efektif menghambat pertumbuhan bakteri dengan persen daya hambat sebesar 16,02\% terhadap bakteri E. coli (G-) dan 14,02\% terhadap bakteri S. aureus $\left(\mathrm{G}^{+}\right)$.

Kata kunci: kitosan, kompleks basa Schiff, rasio substitusi, antibakteri
\end{abstract}

\section{Abstract}

This study was aimed at obtaining the complex of Mn(II)-Schiff base chitosansalicylaldehyde and evaluating the activity of antibacterial agent on cotton fabric. The study was conducted through three treatment steps. In the first step, chitosan-salicylaldehyde Schiff base was synthesized by reacting chitosan with mole variations of salicylaldehyde and combined with a mixture of acetic acid and ethanol as the solvent which was then stirred at $50^{\circ} \mathrm{C}$ for 6 hours. In the second step, preparation complexes Mn(II)- Schiff base chitosan-salicylaldehyde was conducted by mixing chitosan-salicylaldehyde Schiff base and $\mathrm{MnCl} 2.2 \mathrm{H} 2 \mathrm{O}$ using acetic acid $2 \%$-ethanol as a solvent at $60^{\circ} \mathrm{C}$ for $12 \mathrm{~h}$. In the third step, the complex was coated onto fabric using spray method and the E. coli $(\mathrm{G}-)$ dan $S$. aureus $\left(\mathrm{G}^{+}\right)$antibacterial test was done to the coated fabric using disk diffusion method. The results showed that 0.00227 mole salicylaldehyde lead to the highest substitution ratio of Schiff base chitosan-salicylaldehyde of 0.122 . The Mn(II)Schiff base chitosan-salicylaldehyde complex was obtained as black powder with a yield of $66 \%$. Cotton fabric that has been coated with the complex, effectively inhibits bacterial growth with a percent inhibition against $E$. coli $\left(\mathrm{G}^{-}\right)$and $S$. aureus $\left(\mathrm{G}^{+}\right)$bacteria of $16.02 \%$ and $14.02 \%$, respectively.

Keywords: chitosan, Schiff base complex, substitution ratio, antibacterial 


\section{PENDAHULUAN}

Tekstil adalah suatu material yang sangat penting karena material tersebut merupakan bahanyang digunakan untuk pembuatan salah satu kebutuhan pokok manusia yaitu pakaian. Berbagai macam tekstil diproduksi sesuai kebutuhan konsumen salah satunya yaitu tekstil antibakteri atau antibacterial cloth. Senyawa yang digunakan pada tekstil yaitu triklosan (2,4,4'-trikloro-2'-hidroksidifenil eter), namun penggunaannya saat ini sudah dilarang dikarenakan apabila terkena sinar matahari dapat terurai membentuk senyawa dioksin yang bersifat toksik. Salah satu senyawa yang dapat digunakan sebagai alternatif pengganti triklosan yaitu kitosan. Selain memiliki sifat sebagai antibakteri, kitosan juga memiliki sifat menarik seperti biokompatibilitas, biodegradabilitas dan produk degradasinya adalah nontoksik, nonimunogenik dan non-karsinogenik (Al-Issa, Abbas, \& Matty, 2017). Kitosan terdiri dari unit $N$-asetilglukosamin dan glukosamin yang dihubungkan melalui ikatan $\beta-(1,4)$ glikosida, adanya gugus amin dan hidroksi bertindak sebagai sisi aktif untuk modifikasi kimia. Modifikasi kimia kitosan salah satunya dibuat menjadi senyawa basa schiff (Verlee, Mincke, \& Stevens, 2017).

Senyawa basa schiff adalah senyawa dengan gugus fungsi $-\mathrm{CH}=\mathrm{N}-$ yang dihasilkan dari reaksi kondensasi antara aldehid dan amina (Rachmawati, Ngadiwiyana,
\& Ismiyarto, 2017). Senyawa basa schiff merupakan struktur penting yang dibutuhkan untuk aktivitas biologi termasuk antibakteri, antijamur, antimalaria, antioksidan dan aktivitas antitumor sehingga dapat meningkatkan aktivitaskitosan (Barbosa etal., 2017). Sintesis senyawa basa schiff dari berbagai senyawa telah dilakukan dan diaplikasikan di bidang medis dan farmasi. Salah satu sintesis senyawa basa schiff dari kitosan adalah sebagai antibakteri. Namun, dalam perkembangannya aktivitas antibakteri dari senyawa basa schiff yang didapat kurang tinggi. Hal tersebut dapat diatasi dengan pembentukan kompleks senyawa basa schiff melalui ikatan koordinasi. Senyawa tersebut bertindak sebagai ligan dengan menyumbangkan elektron bebasnya untuk ion logam pusat sehingga didapatkan senyawa basa schiff yang lebih stabil dan aktivitas antibakterinya lebih tinggi. Hal ini dapat digunakan sebagai bahan aktif kain antibakteri.

Penelitian Pervaiz et al. (2019) melaporkan sintesis senyawa kompleks basa schiff $\mathrm{Mn}(\mathrm{II})$ dari leusin dan salisaldehid memiliki aktivitas antibakteri yang cukup tinggi. Penelitian mengenai sintesis senyawa kompleks Mn(II) basa schiff kitosansalisaldehid dari kitosan dan salisaldehid sebagai bahan aktif kain antibakteri belum pernah dilaporkan. Dalam penelitian ini dilakukan sintesis basa schiff kitosan- 
salisilaldehid dari kitosan dengan tujuh variasi mol salisilaldehid yaitu 0,0004; 0,00068; 0,00121; 0,00174; 0,00227; 0,0028; 0,00333 mol. Produk yang memiliki rasio substitusi paling tinggi selanjutnya dibuat kompleks dengan ion logam Mn menghasilkan kompleks Mn(II) basa schiff kitosan-salisilaldehid untuk kemudian diuji aktivitas antibakterinya.

\section{METODE PENELITIAN}

Alat-alat yang digunakan pada penelitian ini adalah alat gelas standar penelitian, viskometer Ubbehlode, satu set alat refluks, neraca analitik, Laminar Air Flow, inkubator Memert IN55, orbital shaker, autoklaf, mikro pipet $10100 \mu \mathrm{L}$, jarum ose, cawan petri, spreader, pinset, Shimadzu UV-1280 UV-Vis (Ultra Violet- Visible) spectrophotometer, Perkin Elmer 96681 Frontier Fourier Transform Infrared (FTIR) spectrophotometer, dan SEM-EDX.

Bahan-bahan yang digunakan dalam penelitian ini adalah salisilaldehid p.a (Merck), kitosan $(\mathrm{DD}=68,42 \%, \mathrm{BM}=$ $124926,47 \mathrm{~g} / \mathrm{mol})$, asam asetat glasial p.a (Merck), $\mathrm{NaOH}$ (Merck), $\mathrm{MnCl}_{2} \cdot \mathrm{H}_{2} \mathrm{O}$ (Merck), etanol teknis, akuades, nutrient agar (Merck), pepton (Merck), ekstrak ragi (Merck), kain katun, kertas saring Whatmann No. 42, pH indikator universal, amoksilin, dan alkohol $70 \%$.

Sintesis Senyawa Basa Schiff Kitosan- salisilaldehid. Tujuh variasi mol salisaldehid 0,0004; 0,00068; 0,00121;0,00174;0,00227; 0,0028; 0,00333 mol masing-masing dilarutkan dalam $10 \mathrm{~mL}$ etanol, kemudian ditambahkan tetes demi tetes ke dalam $1 \mathrm{~g}$ kitosan $(0,0028 \mathrm{~mol})$ yang telah dilarutkan dengan $50 \mathrm{~mL}$ larutan asam asetat 2\% (v/v). Campuran larutan distirer dan dipanaskan selama 6 jam pada suhu $50^{\circ} \mathrm{C}$. Produk yang dihasilkan diendapkan dengan $\mathrm{NaOH}$ 5\% (w/v) sampai endapan tidak terbentuk lagi. Endapan yang diperoleh kemudian disaring dan dicuci dengan akuades serta etanol, setelah itu dikeringkan dengan oven pada suhu $60^{\circ} \mathrm{C}$.

Sintesis Senyawa Kompleks Mn(II) Basa Schiff Kitosan-salisilaldehid. Senyawa kitosan-salisilaldehid hasil sintesis sebanyak $0,2 \mathrm{~g}$ dilarutkan dalam $10 \mathrm{~mL}$ pelarut asam asetat $2 \%$ dan $0,15 \mathrm{~g} \mathrm{MnCl}_{2}$ dalam pelarut etanol ditambahkan perlahan-lahan ke dalam larutan kitosan-salisilaldehid. Campuran distirer dan dipanaskan selama 12 jam pada suhu $60^{\circ} \mathrm{C}$. produk yang dihasilkan diendapkan menggunakan $\mathrm{NaOH} \quad 5 \%$ kemudian disaring. Hasil penyaringan dicuci dengan akuades dan etanol untuk selanjutnya dilakukan pengeringan dengan oven.

Pengujian Aktivitas Antibakteri. Sebanyak $1 \mathrm{~g}$ nutrient agar dilarutkan dalam 50 mL akuades yang telah berisi 0,025 g ekstrak ragi dan $0,125 \mathrm{~g}$ pepton. Campuran diaduk kemudian dilakukan sterilisasi menggunakan 
autoklaf selama 1 jam bersama dengan jarum ose dan tabung reaksi. Penanaman bakteri dilakukan dalam Laminar Air Flow. Media agar dimasukan ke dalam tabung reaksi dan diletakan dengan kemiringan $\pm 30^{\circ}$. Koloni bakteri Staphylococcus aureus dan Escherichia coli ditanam ke dalam media agar miring dalam tabung reaksi dengan cara digores menggunakan jarum ose. Hasil penanaman bakteri diinkubasi selama 18-24 jam.

Pembuatan Inokulum Bakteri. Sebanyak $0,05 \mathrm{~g}$ ekstrak ragi dan $0,25 \mathrm{~g}$ pepton dilarutkan dalam $100 \mathrm{~mL}$ akuades. Campuran diaduk dan dimasukan ke dalam tiga buah erlenmeyer kemudian dilakukan sterilisasi menggunakan autoklaf selama 1 jam bersama jarum ose. Stok bakteri yang telah diinkubasi selama 24 jam disuspensikan ke dalam media nutrien broth. Suspensi bakteri diinkubasi selama 2 jam dalam inkubator shaker. Pengukuran absorbansi dilakukan setiap 2 jam sekali pada panjang gelombang 600 $\mathrm{nm}$ untuk mendapatkan kekeruhan suspensi bakteri yang sama dengan kekeruhan larutan standar skala 0,5 McFarland.

Preparasi Larutan Senyawa Uji. Larutan uji dibuat dengan melarutkan $10 \mathrm{mg}$ tujuh sampel senyawa basa schiff kitosansalisilaldehid, kitosan dan senyawa kompleks $\mathrm{Mn}$ (II) basa schiff kitosan-salisilaldehid dalam $10 \mathrm{~mL}$ larutan asam asetat $1 \%$ untuk memberikan konsentrasi $1000 \mu \mathrm{g} / \mathrm{ml}$. Asam asetat $1 \%$ digunakan sebagai kontrol negatif dan amoksilin digunakan sebagai kontrol positif.

Pembuatan Media Uji. Sebanyak 0,05 $\mathrm{g}$ ekstrak ragi dan $0,25 \mathrm{~g}$ pepton serta $2 \mathrm{~g}$ nutrient agar dilarutkan dalam $100 \mathrm{~mL}$ akuades. Campuran diaduk hingga homogen, kemudian dilakukan sterilisasi menggunakan autoklaf selama 1 jam bersama cawan petri. Sebanyak $20 \mathrm{~mL}$ media nutrien agar dituang ke dalam cawan petri lalu dibiarkan media nutrien agar memadat.

Uji Aktivitas Antibakteri. Suspensi bakteri yang telah memenuhi kekeruhan larutan standar konsentrasi 0,5 McFarland diinokulasikan ke media nutrient agar yang telah memadat sebanyak $75 \mu \mathrm{L}$. Sebanyak 10 $\mu \mathrm{L}$ larutan uji diteteskan pada kertas cakram hingga larutan uji terdifusi sempurna. Kertas cakram kemudian diletakkan pada permukaan media nutrient agar sebagai media uji untuk selanjutnya diinkubasi selama 24 jam. Dalam penelitian ini, larutan amoksilin digunakan sebagai kontrol positif dan larutan asam asetat digunakan sebagai kontrol negatif. Zona bening yang terlihat diukur diameternya dalam satuan milimeter.

Pelapisan Kain dengan Metode Spray. Pelapisan senyawa antibakteri pada kain katun dilakukan dengan metode spray. Kain katun berukuran $10 \times 10 \mathrm{~cm}^{2}$ terlebih dahulu dicuci dan dibilas menggunakan akuades, kemudian dengan oven pada suhu $60^{\circ} \mathrm{C}$ selama 30 
menit. Kain yang telah kering ditautkan pada plat kaca untuk disemprot dengan larutan sampel kompleks Mn(II) basa schiff kitosan-salisilaldehid $\pm 4 \mathrm{~mL}$ menggunakan Air brush dengan jarak penyemprotan $10 \mathrm{~cm}$, selanjutnya kain dikeringkan dengan oven pada suhu $60^{\circ} \mathrm{C}$ selama 30 menit dan dimantapkan pada suhu $150^{\circ} \mathrm{C}$ selama 3 menit.

Uji Aktivitas Kain Antibakteri. Uji aktivitas kain antibakteri dilakukan dengan metode turbidimetri. Kain tanpa pelapisan, kain yang dilapisi asam asetat $1 \%$ dan kain yang dilapisi senyawa kompleks $\mathrm{Mn}(\mathrm{II})$ basa schiff kitosan-salisilaldehid berukuran $3 \times 3$ $\mathrm{cm}^{2}$ masing-masing dimasukkan ke dalam erlenmeyer berisi $25 \mathrm{~mL}$ media cair kemudian disterilisasi selama 1 jam menggunakan autoklaf. Bakteri uji yaitu Staphylococcus aureus dan Escherichia coli masing-masing sebanyak $1 \mathrm{~mL}$ yang telah di-shaker selama 24 jam dimasukkan ke dalam media yang telah berisi sampel kemudian diinkubasi pada suhu $37^{\circ} \mathrm{C}$ untuk selanjutnya diukur absorbansinya pada jam ke $0,6,8$ dan 12 menggunakan spektrofotometer uv-vis pada panjang gelombang $600 \mathrm{~nm}$. Data absorbansi tersebut digunakan untuk menghitung persen daya hambat kain antibakteri terhadap pertumbuhan bakteri uji.

$$
\% \text { inhibisi }=\frac{\left(A_{0}-A_{t}\right)-\left(B_{0}-B_{t}\right)}{\left(A_{0}-A_{t}\right)} \times 100 \%
$$

Keterangan:

$\mathrm{A}_{0}=$ jumlah bakteri kontrol jam ke-0
$A_{t}=$ jumlah bakteri kontrol jam ke-t

$\mathrm{B}_{0}=$ jumlah bakteri sampel jam ke-0

$\mathrm{B}_{\mathrm{t}}=$ jumlah bakteri sampel jam ke-t

\section{HASIL DAN PEMBAHASAN}

Produk reaksi kondensasi dari salisilaldehid dan kitosan menghasilkan padatan berwarna kuning pucat yang dianalisis menggunakan spektrofotometer UV-Vis. Spektrum UV-Vis kitosan dan produk reaksi kondensasi dari kitosan dan salisilaldehid dengan tujuh variasi mol salisilaldehid ditunjukkan oleh Gambar 1.

Senyawa kitosan menghasilkan dua pita serapan pada daerah $235 \mathrm{~nm}$ (pita I) yang merupakan transisi $\pi \rightarrow \pi^{*}$ gugus karbonil ( $>\mathrm{C}=\mathrm{O}^{-}$) dan $271 \mathrm{~nm}$ (pita II) yang merupakan transisi $\mathrm{n} \rightarrow \pi^{*}$ gugus hidroksi $(\mathrm{OH})$ terisolasi. Pada senyawa basa schiff kitosan-salisilaldehid dengan tujuh variasi mol salisilaldehid menghasilkan dua pita serapan pada daerah 254-255 nm (pita I) yang merupakan transisi $\pi \rightarrow \pi^{*}$ gugus imina $(>\mathrm{C}=\mathrm{N}-)$ dan konjugasi cincin benzena tersubstitusi gugus hidroksi $(\mathrm{OH})$ dan $292-$ $323 \mathrm{~nm}$ (pita II) yang merupakan transisi $\mathrm{n} \rightarrow \pi^{*}$ gugus imina $(>\mathrm{C}=\mathrm{N}-$ ) dan konjugasi cincin benzena tersubstitusi gugus hidroksi $(\mathrm{OH})$. Data serapan panjang gelombang senyawa basa schiff kitosan-salisilaldehid dengan tujuh variasi mol salisilaldehid ditunjukkan pada Tabel 1. 


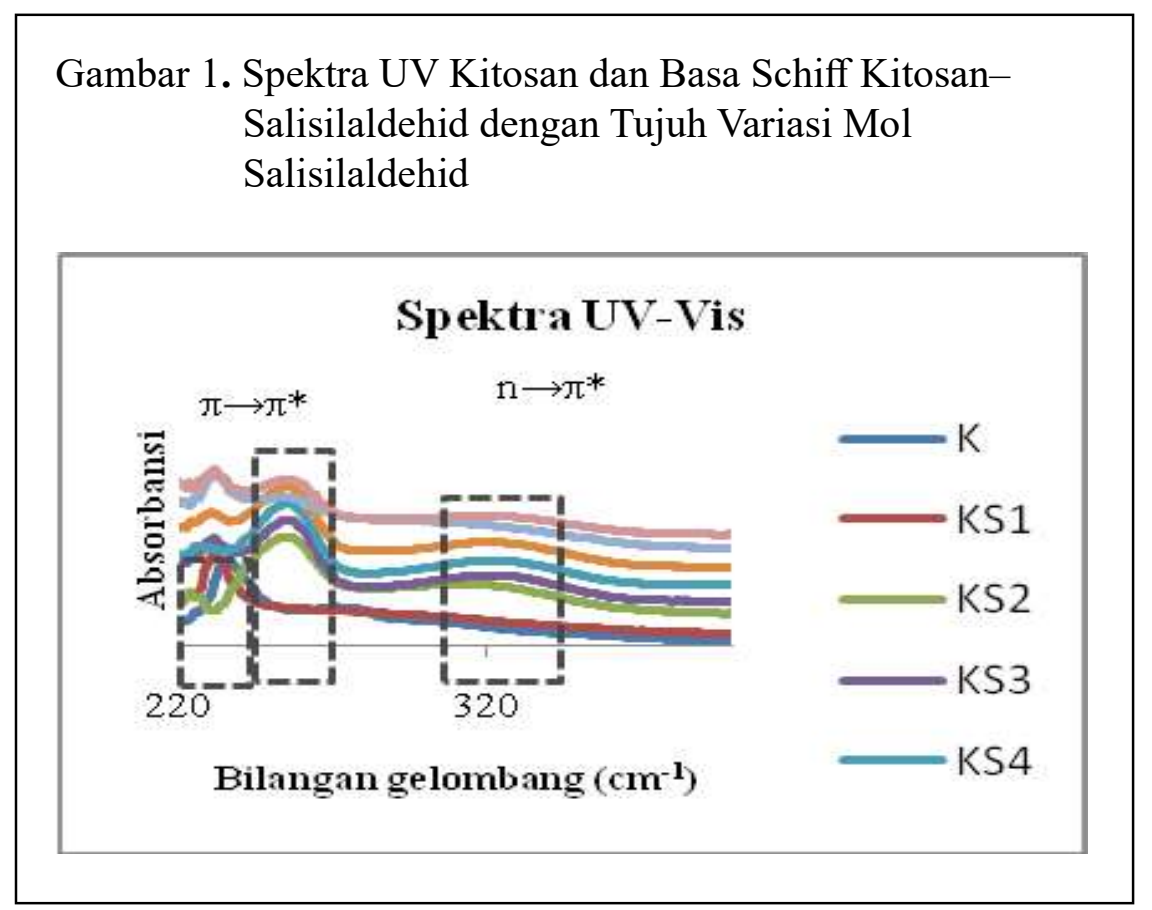

Tabel 1

Data Serapan Panjang Gelombang Kitosan dan Basa Schiff Kitosan-Salisilaldehid

\begin{tabular}{cccc}
\hline \multirow{2}{*}{ Sampel } & $\begin{array}{c}\text { Variasi mol } \\
\text { salisilaldehid }\end{array}$ & \multicolumn{2}{c}{ Panjang Gelombang (nm) } \\
\cline { 3 - 4 } & & Pita I & Pita II \\
\hline K & 0,0004 & 235 & 271 \\
KS1 & 0,00068 & 252 & 291 \\
KS3 & 0,00121 & 255 & 313 \\
KS4 & 0,00174 & 255 & 321 \\
KS5 & 0,00227 & 255 & 322 \\
KS6 & 0,0028 & 254 & 322 \\
KS7 & 0,00333 & 255 & 292 \\
\hline
\end{tabular}

Keterangan:

$\mathrm{K}=$ kitosan.

$\mathrm{KS} 1, \mathrm{KS} 2, \mathrm{KS} 3, \mathrm{KS} 4, \mathrm{KS} 5, \mathrm{KS} 6, \mathrm{KS} 7=$ senyawa basa schiff kitosan-salisilaldehid dengan tujuh variasi mol salisilaldehid 0,$0004 ; 0,00068 ; 0,00121 ; 0,00174 ; 0,00227$; 0,0028; $0,00333 \mathrm{~mol}$.

Karakterisasi lebih lanjut dilakukan menggunakan alat spektrofotometer inframerah untuk mengkonfirmasi perubahan gugus karbonil $(>\mathrm{C}=\mathrm{O}-$ ) pada kitosan menjadi gugus imina $(>\mathrm{C}=\mathrm{N}-)$ berdasarkan serapan gelombangnya. Spektrum inframerah 
kitosan menunjukan adanya serapan gugus karbonil ( $>\mathrm{C}=\mathrm{O}-$ ) pada bilangan gelombang $1644,32 \mathrm{~cm}^{-1}$ sedangkan pada senyawa basa schiff kitosan-salisilaldehid dengan tujuh variasi mol salisilaldehid terjadi pergeseran serapan menuju bilangan gelombang lebih rendah yaitu 1640,$08 ; 1643,15 ; 1639,14$; 1638,$39 ; 1640,83 ; 1641,69 ; 1641,86 \mathrm{~cm}^{-1}$ yang menunjukkan adanya serapan gugus imina $(>\mathrm{C}=\mathrm{N}-)$. Adanya pergeseran tersebut dapat disimpulkan bahwa senyawa basa schiff telah terbentuk. Analisis dengan spektofotometer inframerah memberikan spektra yang ditunjukan pada Gambar 2.

Sintesis senyawa kompleks Mn(II) basa schiffkitosan-salisilaldehid diperoleh dengan mereaksikan senyawa basa schiff kitosansalisilaldehid dengan larutan $\mathrm{MnCl}_{2} \cdot 2 \mathrm{H}_{2} \mathrm{O}$. Kompleks basa schiff dapat terbentuk karena adanya ikatan koordinasi yang terjadi antara gugus $\mathrm{C}=\mathrm{N}$ dan gugus $\mathrm{OH}$ pada basa schiff kitosan-salisilaldehid dengan logam Mn. Pasangan elektron bebas yang terdapat pada atom $\mathrm{N}$ gugus $\mathrm{C}=\mathrm{N}$ dan atom $\mathrm{O}$ pada gugus $\mathrm{OH}$ menyebabkan basa schiff bertindak sebagai ligan dengan mendonorkan pasangan elektron bebasnya kepada ion Mn yang bertindak sebagai ion logam pusat. Produk reaksi merupakan padatan berwarna hitam yang diperoleh dari proses pengendapan oleh larutan $\mathrm{NaOH}$ disertai pencucian dengan pelarut akuades serta etanol dan pengeringan dengan oven. Massa produk yang diperoleh sebesar 0,2294 g.

Pembentukan senyawa kompleks menyebabkan munculnya peak baru pada daerah di sekitar $400 \mathrm{~nm}$ yang menunjukan adanya transisi orbital $\mathrm{d} \rightarrow \mathrm{d}$ yang terjadi

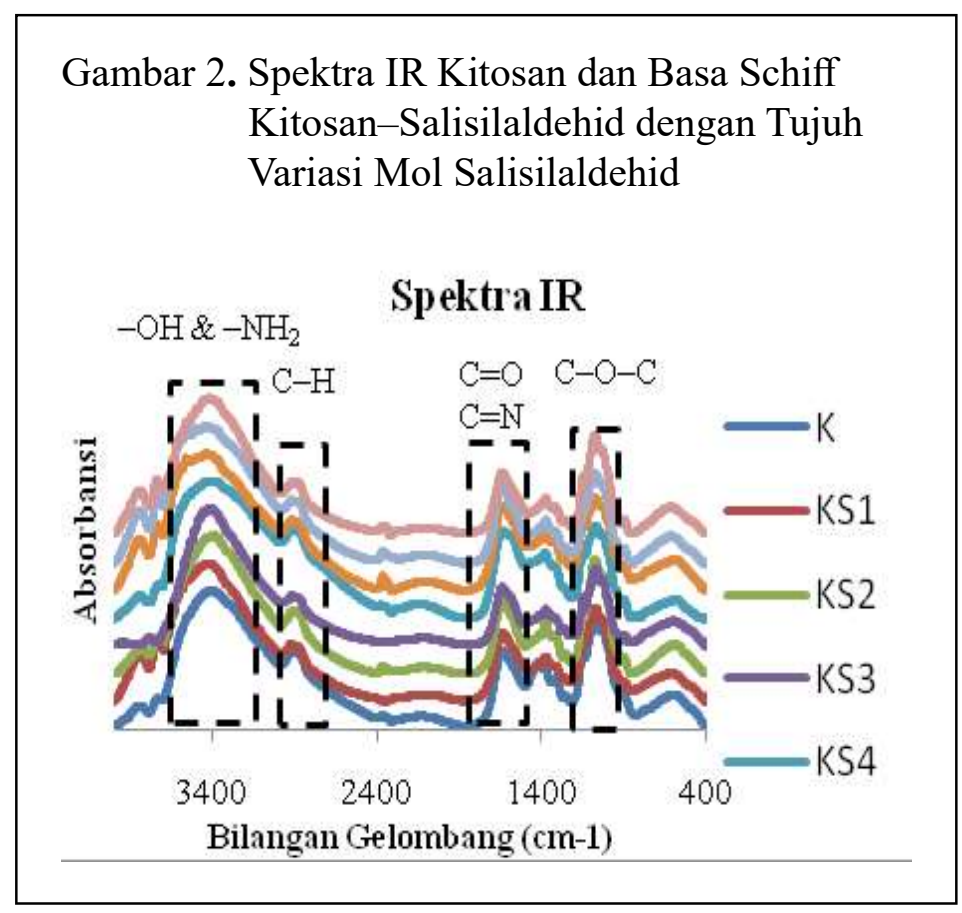


pada logam pusat, namun hasil spektra uvvis tidak menghasilkan peak pada daerah tersebut sehingga dilakukan dekonvulasi untuk mengetahui adanya transisi orbital $\mathrm{d} \rightarrow \mathrm{d}$.

Dekonvolusi senyawa kompleks $\mathrm{Mn}$ (II) basa schiff kitosan-salisilaldehid menghasilkan empat peak (Gambar 3b) sedangkan dekonvulasi senyawa basa schiff kitosan-salisilaldehid menghasilkan tiga peak (Gambar 3a). Dekonvulasi senyawa basa schiff kitosan-salisilaldehid menghasilkan tiga peak. Masing-masing peak merupakan transisi dari $\pi \rightarrow \pi^{*}$ gugus karbonil $(>\mathrm{C}=\mathrm{O}-), \pi \rightarrow \pi^{*}$ gugus imina $\left(>\mathrm{C}=\mathrm{N}^{-}\right)$dan konjugasi cincin benzena tersubstitusi gugus hidroksi $(\mathrm{OH})$ dan $\mathrm{n} \rightarrow \pi^{*}$ gugus imina $(>\mathrm{C}=\mathrm{N}-$ ) dan konjugasi cincin benzena tersubstitusi gugus hidroksi $(\mathrm{OH})$. Adanya peak baru yang muncul pada daerah $412 \mathrm{~nm}$ merupakan transisi dari orbital $\mathrm{d} \rightarrow \mathrm{d}$ pada logam Mn yang merupakan atom pusat.

Karakterisasi lebih lanjut dilakukan dengan menggunakan spektrofotometer inframerah untuk mengonfirmasi terbentuknya senyawa kompleks Mn(II) basa schiff kitosan-salisilaldehid. Analisis dengan spektofotometer inframerah memberikan spektra yang ditunjukan pada Gambar 4.

Spektrum inframerah senyawa kompleks $\mathrm{Mn}(\mathrm{II})$ basa schiff kitosansalisilaldehid menunjukkan pergeseran serapan gugus imina $(>\mathrm{C}=\mathrm{N}-)$ menuju bilangan gelombang yang lebih rendah yaitu $1630,69 \mathrm{~cm}^{-1}$ yang menandakan koordinasi basa schiff dengan ion logam pusat. Puncak khas senyawa kompleks terlihat pada daerah gugus fungsi yaitu adanya serapan pada bilangan gelombang $612,92 \mathrm{~cm}^{-1}$ yang

Gambar 3. Dekonvolusi Spektra UV-Vis (a) Basa Schiff Kitosan-Salisilaldehid, (b) Kompleks Mn(II) Basa Schiff Kitosan-Salisilaldehid

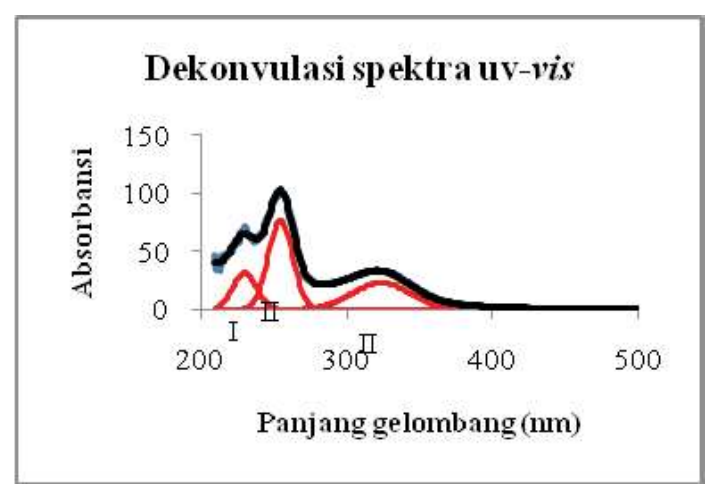

a

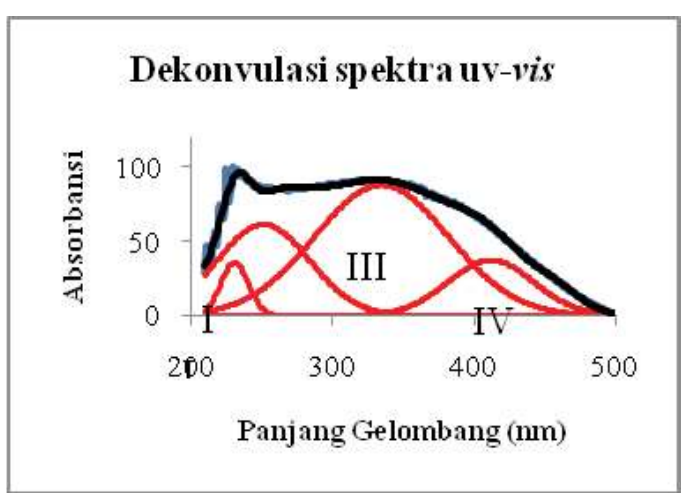

$\mathrm{b}$ 


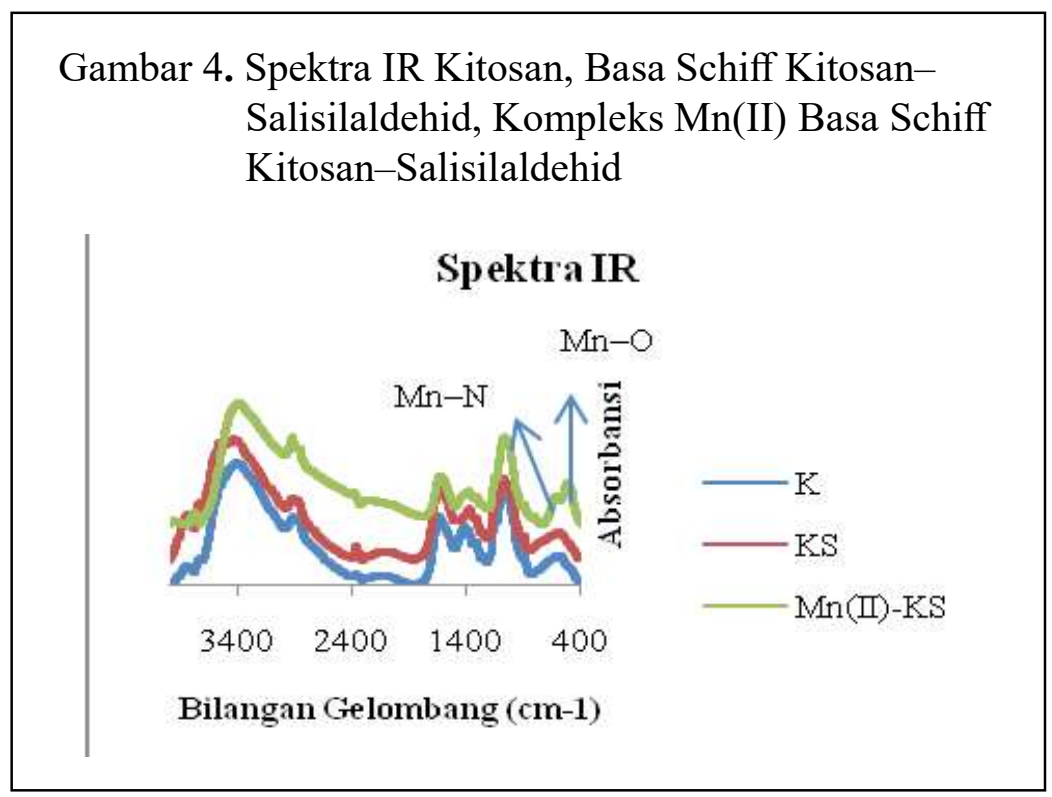

menandakan vibrasi ikatan $\mathrm{Mn}-\mathrm{N}$ dan 516,08 $\mathrm{cm}^{-1}$ yang menandakan vibrasi ikatan $\mathrm{Mn}-\mathrm{O}$.

Karakterisasi dilakukan dengan SEMEDX untuk mengetahui persen komposisi unsur yang ada pada kompleks Mn(II) basa schiff kitosan-salisilaldehid. Analisis SEMEDX kompleks Mn(II) basa schiff kitosan- salisilaldehid diambil dari lima titik berbeda ditunjukan oleh Gambar 5.

Komposisi unsur yang terdapat pada senyawa kompleks $\mathrm{Mn}(\mathrm{II})$ basa schiff kitosan-salisilaldehid ditunjukkan pada Tabel 2. Tabel 2 menunjukkan bahwa unsur mangan (Mn) paling dominan pada titik 2,3

\section{Gambar 5. Hasil SEM Senyawa Kompleks Mn(II) Basa Schiff Kitosan-Salisilaldehid pada Lima Titik Berbeda}

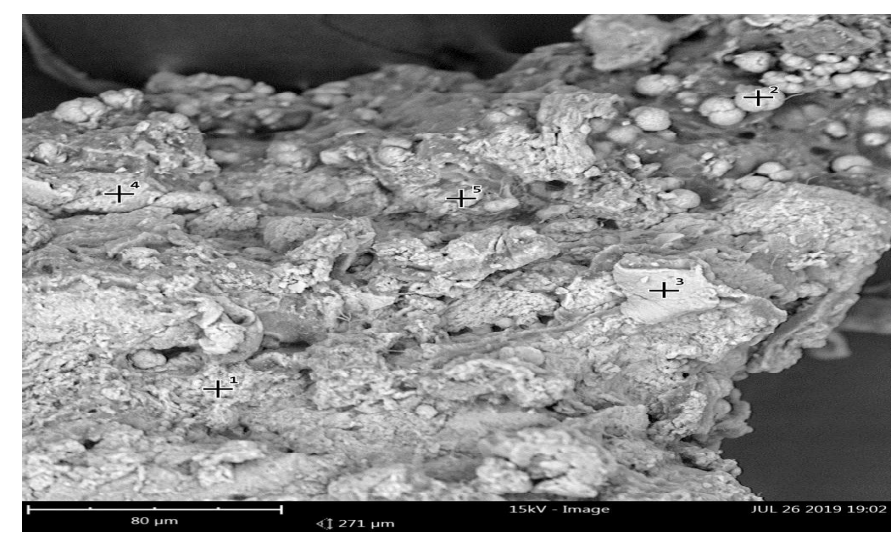


Jurnal Penelitian Saintek, Vol. 25, Nomor 1, 2020

Tabel 2

Hasil Analisis EDX Senyawa Kompleks Mn(II) Basa Schiff

Kitosan-Salisilaldehid

\begin{tabular}{cccccc}
\hline \multirow{2}{*}{ Unsur } & \multicolumn{5}{c}{ Berat (\%) } \\
\cline { 2 - 6 } & Titik 1 & Titik 2 & Titik 3 & Titik 4 & Titik 5 \\
\hline Mn & 29,4 & 48,1 & 54,1 & 55,1 & 24,9 \\
O & 49,2 & 36,3 & 29,7 & 28,5 & 55,3 \\
C & 11,6 & 10,3 & 10,2 & 10,1 & 12,6 \\
N & 9,8 & 5,3 & 6 & 6,2 & 7,2 \\
\hline
\end{tabular}

dan 4 masing-masing sebesar 48,1\%, 54,1\% dan 55,3\%. Adanya unsur Mn dalam analisis EDX menunjukkan bahwa kompleks sudah terbentuk.

Hasil uji aktivitas antibakteri menunjukkan bahwa sampel kitosan, kitosansalisilaldehid, kompleks $\mathrm{Mn}(\mathrm{II})$ basa schiff kitosan-salisilaldehid menghasilkan zona bening yang lebih besar terhadap bakteri Escherichia coli $\left(\mathrm{G}^{-}\right)$dibanding bakteri Staphylococcus aureus $\left(\mathrm{G}^{+}\right)$, sehingga dapat disimpulkan bahwa sampel memiliki sensitifitas lebih tinggi terhadap bakteri Escherichia coli $\left(\mathrm{G}^{-}\right)$dibanding bakteri Staphylococcus aureus $\left(\mathrm{G}^{+}\right)$. Perbedaan sensitifitas tersebut dapat disebabkan karena adanya perbedaan struktur membran sel masing-masing bakteri (Lopez-Romero, González-Ríos, Borges, \& Simões, 2015).

Perbedaan struktur membran sel bakteri dapat dilihat dari komponen penyusun membran sel luar dan dinding selnya. Bakteri gram positif dikelilingi oleh dinding sel yang terdiri dari beberapa lapisan peptidoglikan yang membentuk struktur tebal dan kaku. Oleh karena itu, sel menjadi sulit ditembus (Silhavy, Kahne, \& Walker, 2010). Bakteri gram negatif dikelilingi oleh dinding sel yang terdiri dari lapisan peptidoglikan yang tipis (Miller \& Salama, 2018). Membran luar bakteri gram negatif tersusun dari fosfolipid dan lipopolisakarida yang memilki bagian hidrofilik dan hidrofobik. Bagian hidrofilik tersebut dapat membentuk ikatan hidrogen dengan senyawa basa schiff yang memiliki gugus imina sehingga menembus lapisan lipoposakarida (Joseyphus \& Nair, 2008).

Senyawa basa schiff memiliki aktivitas antibakteri lebih besar dibanding kitosan. Hal tersebut dikarenakan adanya gugus imina yang terdapat pada senyawa basa schiff memiliki elektron bebas pada atom nitrogennya sehingga dapat membentuk ikatan hidrogen dengan pusat aktif sel yang akan mengganggu proses normal sel. Adanya substituen $\mathrm{OH}$ pada kerangka basa schiff juga dapat meningkatkan aktivitas antibakterinya (Matar, Talib, Mustafa, Mubarak, \& AlDamen, 2015). 
Aktivitas antibakteri senyawa kompleks Mn(II) basa schiff kitosan-salisilaldehid disebabkan oleh meningkatnya kepadatan muatan positif senyawa kompleks yang menyebabkan interaksi antara senyawa dengan muatan negatif bakteri meningkat. Khelat yang terbentuk dari ion logam Mn dan ligan basa schiff kitosan-salisilaldehid akan berinteraksi dengan permukaan sel bakteri sehingga pertumbuhan sel bakteri terganggu. Hasil uji aktivitas antibakteri ditunjukan pada Tabel 3 .

Hasil analisis permukaan kain sebelum coating maupun setelah coating menggunakan mikroskop pada perbesaran 4x maupun perbesaran 10x tidak menunjukkan perbedaan yang signifikan. Artinya, serat kain katun yang telah dilapisi senyawa kompleks Mn(II) basa schiff kitosan- salisilaldehid tidak mengalami kerusakan. Hasil analisis dengan mikroskop ditunjukkan pada Gambar 6.

Pada uji antibakteri digunakan bakteri uji Eschericia coli dan Staphylococcus aureus karena kedua bakteri tersebut banyak ditemukan pada pakaian pasien yang dirawat di rumah sakit (Callewaert et al., 2014). Hasil persen daya hambat kain antibakteri ditunjukkan pada Gambar 7. Grafik tersebut menunjukkan bahwa persen daya hambat kain antibakteri terhadap bakteri Eschericia coli $\left(\mathrm{G}^{-}\right)$lebih tinggi dibandingkan bakteri Staphylococcus aureus $\left(\mathrm{G}^{+}\right)$. Hal ini dikarenakan dinding sel bakteri Eschericia coli $\left(\mathrm{G}^{-}\right)$yang merupakan bakteri gram negatif terdiri dari lapisan peptidoglikan yang tipis. Selain itu, membran luar sel bakteri gram negatif tersusun dari fosfolipid

Tabel 3

Hasil Uji Aktivitas Antibakteri Senyawa Kompleks Mn(II)

Basa Schiff Kitosan-Salisilaldehid

\begin{tabular}{cccc}
\hline \multirow{2}{*}{ Sampel } & \multirow{2}{*}{ C $(\mathrm{mg} / \mathrm{mL})$} & \multicolumn{2}{c}{ Zona Hambat $(\mathrm{mm})$} \\
\cline { 3 - 4 } & & E. coli & S.aureus \\
\hline Kitosan & 1 & 5 & 4 \\
KS5 & 1 & 6 & 5 \\
Mn-KS & 1 & 8 & 7 \\
$(+)$ & 0,01 & 6 & 3 \\
$(-)$ & 10 & 4 & 4 \\
\hline
\end{tabular}

Keterangan:

C : Konsentrasi, (+) : amoksilin, (-) : asam asetat

KS5 : senyawa basa schiff kitosan-salisilaldehid variasi $0,00227 \mathrm{~mol}$ salisilaldehid

Mn-KS : senyawa kompleks Mn(II) basa schiff kitosan-salisilaldehid dengan variasi 0,00227 mol salisilaldehid 


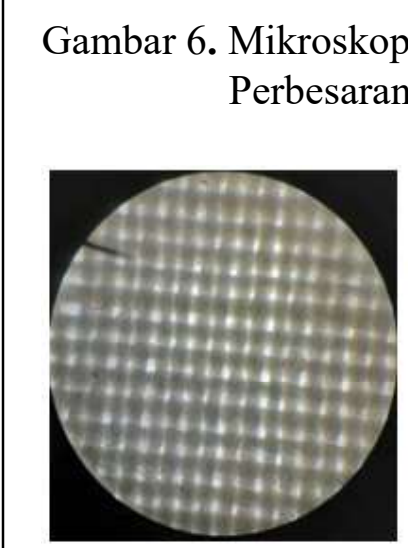

(a)

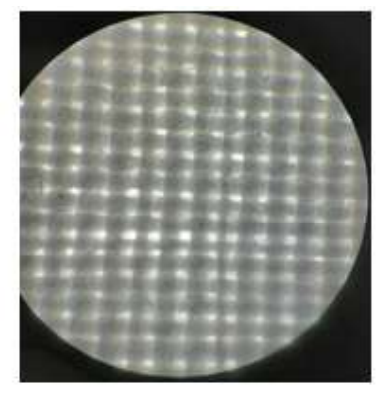

(b)

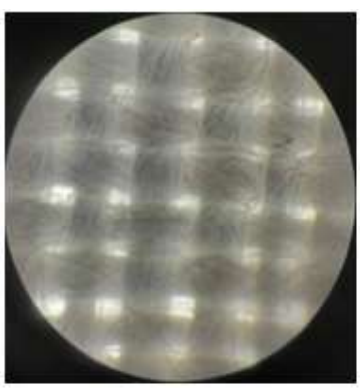

(c)

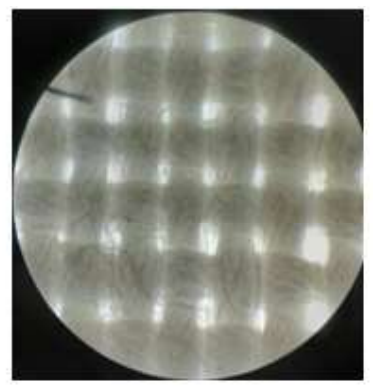

(d) dan lipopolisakarida yang memiliki bagian hidrofilik dan hidrofobik. Bagian hidrofilik tersebut dapat membentuk ikatan hidrogen dengan gugus imina pada senyawa basa schiff sehingga dapat menembus lapisan lipopolisakarida bakteri, sedangkan pada bakteri Staphylococcus aureus $\left(\mathrm{G}^{+}\right)$yang merupakan bakteri gram negatif dinding selnya mengandung banyak lapisan peptidoglikan yang membentuk struktur yang tebal dan kaku sehingga lebih sulit ditembus.

Gambar 7 menunjukkan bahwa persen daya hambat kain antibakteri terhadap dua bakteri uji paling tinggi pada pengukuran jam ke-6, sehingga dapat disimpulkan bahwa kemampuan kain antibakteri dalam menghambat pertumbuhan bakteri efektif pada enam jam pertama, karena setelah jam ke-6 bakteri akan tumbuh kembali.

Gambar 7. Grafik Persen Daya Hambat Kain Antibakteri

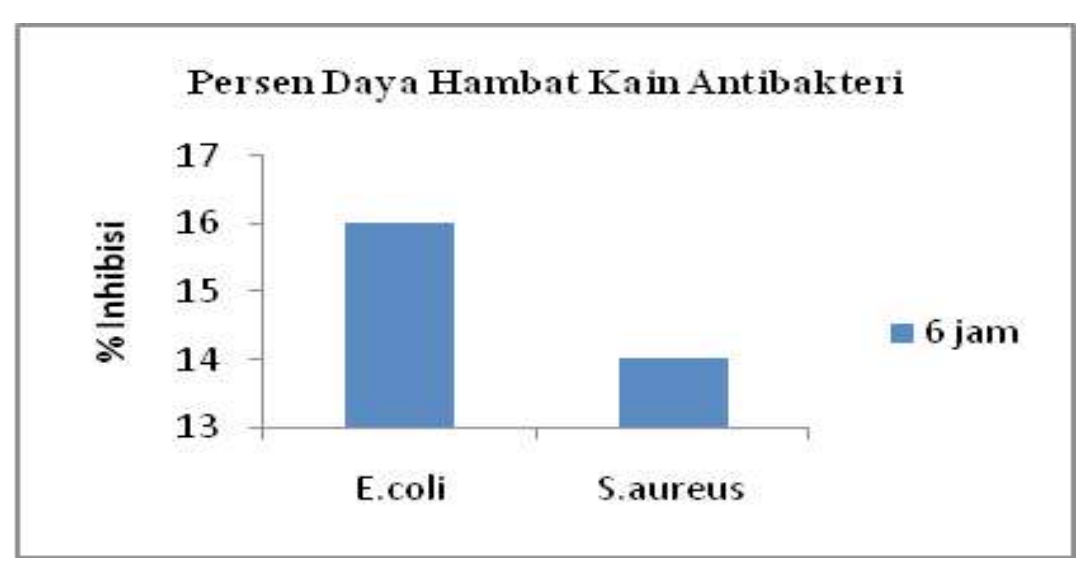




\section{SIMPULAN}

Aplikasi senyawa kompleks $\mathrm{Mn}(\mathrm{II})$ basa schiff kitosan-salisilaldehid mampu digunakan sebagai kain antibakteri, dan efektif menghambat pertumbuhan bakteri pada jam ke-6 dengan menghasilkan persen daya hambat sebesar $16,02 \%$ terhadap bakteri Eschericia coli $\left(\mathrm{G}^{-}\right)$dan 14,02\% terhadap bakteri Staphylococcus aureus $\left(\mathrm{G}^{+}\right)$

\section{DAFTAR PUSTAKA}

Al-Issa, M. A., Abbas, A. A., \& Matty, F. S. (2017). Synthesis and characterization of schiff base derived from chitosan and its complexes with $(\mathrm{Co}+2, \mathrm{Ni}+2$ and $\mathrm{Cu}+2$ ). Ibn AL-Haitham Journal For Pure and Applied Science, 29(2), 115129.

Barbosa, H. F. G., Attjioui, M., Ferreira, A. P. G., Dockal, E. R., El Gueddari, N. E., Moerschbacher, B. M., \& Cavalheiro, É. T. G. (2017). Synthesis, characterization and biological activities of biopolymeric Schiff bases prepared with chitosan and salicylaldehydes and their Pd (II) and Pt (II) complexes. Molecules, 22(11), 1987.

Callewaert, C., De Maeseneire, E., Kerckhof, F. M., Verliefde, A., Van de Wiele, T., \& Boon, N. (2014). Microbial odor profile of polyester and cotton clothes after a fitness session. Applied and environmental microbiology, 80(21), 6611-6619.

Joseyphus, R. S., \& Nair, M. S. (2008). Antibacterial and antifungal studies on some schiff base complexes of zinc (II). Mycobiology, 36(2), 93-98.

Lopez-Romero, J. C., González-Ríos, H., Borges, A., \& Simões, M. (2015).
Antibacterial effects and mode of action of selected essential oils components against Escherichia coli and Staphylococcus aureus. EvidenceBased Complementary and Alternative Medicine, 2015.

Matar, S. A., Talib, W. H., Mustafa, M. S., Mubarak, M. S., \& AlDamen, M. A. (2015). Synthesis, characterization, and antimicrobial activity of Schiff bases derived from benzaldehydes and 3, 3'-diaminodipropylamine. Arabian Journal of Chemistry, 8(6), 850-857.

Miller, S. I., \& Salama, N. R. (2018). The gram-negative bacterial periplasm: Size matters. PLoS biology, 16(1), p. e2004935.

Pervaiz, M., Ahmad, I., Yousaf, M., Kirn, S., Munawar, A., Saeed, Z., ... \& Rashid, A. (2019). Synthesis, spectral and antimicrobial studies of amino acid derivative Schiff base metal (Co, $\mathrm{Mn}, \mathrm{Cu}$, and $\mathrm{Cd}$ ) complexes. Spectrochimica Acta Part A: Molecular and Biomolecular Spectroscopy, 206, 642-649.

Rachmawati, I. E., Ngadiwiyana, \& Ismiyarto. (2017). Sintesis turunan azomethin sebagai zat aktif inhibitor korosi pada logam menggunakan bahan dasar piperonal dan 2-aminopiridin. Jurnal Kimia Sains dan Aplikasi, 20(3), 136-139.

Silhavy, T. J., Kahne, D., \& Walker, S. (2010). The bacterial cell envelope. Cold Spring Harb Perspect Biol., 2(5): a000414.

Verlee, A., Mincke, S., \& Stevens, C. V. (2017) Recent developments in antibacterial and antifungal chitosan and its derivatives. Carbohydrate Polymers, 164, 268-283. 